\title{
Elementi poganske tradicije u pozadini predbožićnih blagdana kod Rusina u Vojvodini
}

\author{
Vladimir Edelinski Mikolka*
}

\begin{abstract}
Sažetak
Članak proučava elemente pretkršćanske tradicije prisutne u pozadini kršćanskih blagdana kod vojvođanskih Rusina. Cilj je rada prikazati utjecaj poganske tradicije na razvoj vanjske forme tih blagdana. Analiza pojedinih narodnih običaja koji se nalaze u pozadini blagdana u predbožićnom periodu, odnosno na početku zimskoga ciklusa, konkretno u pozadini blagdana sv. Andrije i sv. Barbare sa sličnim elementima koji su prisutni u poganskim običajima na početku ljetnoga ciklusa, daje nam mogućnost primijetiti da elementi poganske tradicije posjeduju svojevrsnu mitološku dijalektiku između svjetla i tame. Istodobno ovo istraživanje osvjetljava nam dio problema s kojima se susretala Crkva prilikom pokrštavanja poganskih naroda.
\end{abstract}

Ključne riječi: Rusini; blagdani; poganska tradicija; svjetlo i tama

\section{Uvod}

Rusini u Vojvodini katolici su koji slijede grčko-bizantsku liturgijsku tradiciju te se stoga nazivaju grkokatolicima. Iz težnje za ponovnim jedinstvom Istočne i Zapadne Crkve njihovi su predci u jedinstvo Crkve ušli po takozvanoj Užgorodskoj uniji 1646. godine, prihvaćajući tako cjelovito dogmatsko učenje Katoličke crkve, ali čuvajući unutarnju organizacijsku i obrednu autonomiju. ${ }^{1}$ Ulaskom u Uniju rusinski narod sa sobom je donio i brojne običaje iz bogate pretkršćanske slavenske tradicije koji su dobrim djelom karakteristično vežu uz pojedine kršćanske blagdane i ostaju tu praktično sve do danas. Tradicija Rusina u Vojvodini usko je povezana s tradicijom Rusina u Vukovarsko-srijemskoj županiji. Tu, kao

* Vladimir Edelinski Mikolka, doktorand, Fakultet filozofije i religijskih znanosti Sveučilišta u Zagrebu. Adresa: Jordanovac 110, 10000 Zagreb, Hrvatska. ORCID iD: https://orcid.org/00000001-8913-9591. E-adresa: mikolka.rk@gmail.com

1 Po Užgorodskoj uniji 1646. godine svojom su se odlukom 63 rusinska pravoslavna svećenika s južnih obronaka planina Karpata, a na teritoriji Kraljevine Ugarske, pridružili Katoličkoj crkvi pod uvjetima sličnim u Brestlitovskoj uniji 1596. godine. Suvremeni je rezultat te unije Rusinska grkokatolička crkva (lat. Ecclesia Graeco-Catholica Ruthenica). 
priznata nacionalna manjina, živi više od dvije trećine Rusina u Hrvatskoj. Živeći na ovim prostorima više stotina godina oni su živuće kulturno blago Hrvatske. ${ }^{2}$

Članak je usmjeren na početak ciklusa središnjega zimskoga blagdana - Božića, gdje se susrećemo s blagdanom sv. Andrije i blagdanom sv. Barbare. Pretkršćanski elementi u pozadini ta dva blagdana pokazuju stoljetnu povezanost $\mathrm{Ru}$ sina ne samo sa starom slavenskom duhovnom tradicijom, nego i s narodima koji proizlaze iz te starine. U bližem rusinskom okruženju to su Hrvati, Rusi, Slovaci, Srbi i Ukrajinci, ali čak i Mađari i Nijemci. Primjerice, među katoličkim i protestantskim stanovništvom u Vojvodini (u Titelu, južnoj Bačkoj, Bečeju) te u naseljima sjeverne Bačke u blizini Mađara (Doroslovo) i Šokaca (Sonta), uoči proslave sv. Lucije (13. prosinca) navečer, maskirane povorke djevojaka s imenom Lucija, Lucika, Luca posjećuju brojna domaćinstva. Istodobno među Hrvatima u Banatu (u Boki i Neuzini), kod Šokaca, Hrvata i Slovaka u Srijemu, sudjelovale su djevojke, njih dvije do pet, odjevene u bijele haljine ili bijele plahte. Glava im je obično prekrivena rešetom, preko koje je prebačen bijeli čaršaf, a na prednje im je zube pričvršćen jedan veći "zub” od krumpira. U rukama su nosile tavu sa žarom ili metle (Marjanović, 2011, 162). Među Slovacima u takvim povorkama sudjelovali su muškarci prerušeni u žene. Jedan od sudionika nosio je jedan šal dolje, a drugi oko vrata — donji je predstavljao suknju, a gornji košulju. Stavili su veliku papirnatu vrećicu na glavu, zube napravljene od krumpira ili mrkve, a kosu vezanu velikom crvenom vrpcom (Gložan) ili su nosili bijelu platnenu masku izrezanu na mjestima za usta, oči i nos (Pivnice). U drugoj spomenutoj varijanti pojavio se je čovjek sa sitom na glavi preko kojega je bio prebačen list bijele boje, u ruci je držao guščje krilo i "udarao” neposlušnu djecu (Selenča) (Marjanović, 2011, 163). Kod Srba u pirotskom kraju postoji samo prisjećanje da su na sv. Barbaru djeca išla skupljati kukuruz i grah od kojega se je kuhalo jelo zvano Varvara (Plotnikova, 2004, 271). Kod Srba u Vojvodini poznato je kuhanje zrna pšenice u više sela u Srijemu, Banatu i u Bačkoj, s tim da je u Bođanima, Berkasovu i Šajkašu bio običaj nositi prvi tanjur kuhane pšenice na groblje, iz čega se može zaključiti da je kuhana pšenica imala i zadušni karakter (Bosić, 1996, 27).

Uspoređujući spomenutu tradiciju s rusinskim običajima u pozadini blagdana sv. Andrije i sv. Barbare cilj nam je pokazati da, iako pojedini elementi spomenutih običaja nisu povezani s istim kršćanskim blagdanom, ipak se u njima naziru obrisi slične, ili iste pretkršćanske tradicije, koja u sebi posjeduje tragove mitskoga suodnosa svjetla i tame. Istodobno, ovo nam istraživanje pomaže primijetiti kako je Kristova Crkva donoseći Radosnu vijest među slavenske narode nastojala razumjeti zatečenu pretkršćansku tradiciju te kako ju je prihvatila kroz njezino ponovno osmišljavanje. Prihvaćajući tu tradiciju i običaje, Crkva je nači-

2 Za potrebe ovoga istraživanja autor je intervjuirao tri kazivača: Melanija Dudaš, rođ. 1935., Rusinka rodom iz Ruskoga Krstura, intervjuirana 7. prosinca 2019. u Ruskom Krsturu; Miron Dudaš, rođ. 1929., Rusin iz Ruskoga Krstura, rođen u Šidu, intervjuiran 25. studenoga 2016. u Ruskom Krsturu; Olgica Lukač, rođ. 1950., Rusinka iz Bikič Dola, intervjuirana 26. siječnja 2019. u Berkasovu. Transkripti intervjua nalaze se u privatnom arhivu autora. 
nila iskorak k cijelomu narodu koji tu tradiciju nasljeduje, a za uzvrat narod je prihvatio Poruku koju mu je Crkva donijela, obogaćujući tako jedni druge.

\section{Predbožićno razdoblje}

\subsection{Pojam Božića kod Rusina}

Glavni kršćanski blagdan kod Rusina tijekom zimskoga razdoblja blagdan je Kristova rođenja, koji se po tradiciji naziva kračun. Etimologiju toga naziva možemo pratiti kod Rusina u Ukrajini i Slovačkoj, gdje njime nazivaju kruh posebno pečen za badnju večer. Povezanost se vidi i s moldavskom riječju krečun, što također znači obredni kruh, ali znači i sam Božić. Rumunjska riječ craciun (čit. "kračun") također znači Božić. Filolog Ramač smatra da su ti izrazi povezani s albanskim kërcun (čit. "kercun”), što znači panj izvađen iz tla (Ramač, 2017, 639). Panj u pretkršćanskim blagdanima balkanskih naroda posebno je istražio etnolog Milovan Gavazzi, koji je utvrdio da je kod balkanskih naroda, također i na hrvatskom području, postojao pretkršćanski blagdan zimskoga sunčanoga solsticija, ${ }^{3}$ tijekom kojega je gotovo ritualno spaljivano drvo, panj ili grana donesena iz šume posebno za tu priliku. On navodi da se je badnjak, kao panj, palio i u Njemačkoj te da ga se tamo nazivalo Julklotz ili Julblock (Gavazzi, 1991, 141). Panj koji se na badnju večer pali u Francuskoj i drugim francuskim jezikom govorećim državama naziva se Bûche de Noël. S vremenom je francuska pučka tradicija panj zamijenila posebnim kolačem istoga imena koji se peče upravo za badnju večer (Bešker, 2004, 166). Možemo primijetiti sličan logički razvoj naziva badnjega kolača prisutnoga kod Rusina u Slovačkoj i Ukrajini, koji obredni kruh badnje večeri nazivaju kračun.

Rusini vrijeme kroz godinu računaju po julijanskom kalendaru, stoga Kračun (Božić) slave 7. siječnja. Dio njih se ravna po gregorijanskom kalendaru, te stoga Kračun slave 25. prosinca. ${ }^{4}$ Stoga neki etimolozi imenicu kračun povezuju s imenicom kračac, što se prevodi kao "koračati", "prekoračiti” ili "iskoračiti”, stoga što u astronomskom smislu kretanje sunca na nebeskom svodu 25. prosinca čini svojevrsni "iskorak" iz razdoblja kratkih dana u razdoblje sve dužih dana, te tako ruski izraz корочун (čit. "koročun”) obilježava zimski sunčani prijelazni dan (Ramač, 2017, 639). U tom smislu kod Rusina postoji narodna poslovica koja kaže da nakon Kračuna dan postaje duži za jedan kokošji korak. Ta poslovica odnosi se na jedan složeni astronomski fenomen te tih nekoliko sekundi dužega sunčanoga razdoblja u danu dosta uspješno predstavlja puku na njemu razumljiv

3 Solsticij je astronomska pojava koja se događa dva puta godišnje kada sunce na nebu opisuje najvišu ili najnižu putanju u odnosu na nebeski ekvator. Toga dana sunce u podne (lokalno sunčevo podne) dostiže najvišu ili najnižu točku na nebu iznad horizonta. Solsticijska kratkodnevica postiže se 22. prosinca i traje tri dana.

4 Veći dio Grkokatoličke crkve u Vojvodini liturgijski život organizira služeći se julijanskim kalendarom. Novi, gregorijanski, kalendar koristi jedino župa u Ruskom Krsturu i njezina podružnica u Subotici. Rusini u Hrvatskoj nakon Domovinskoga rata prihvatili su gregorijanski kalendar. 
način. Dobro je istaknuti i to da se pri opisivanju toga fenomena koristi izraz korak (kokošji) ili koračati, koji, kako smo već rekli slikovito ali ipak točno, opisuje astronomski fenomen koji se tada zbiva — zimski sunčani prijelazni dan iz razdoblja kraćih dana, odnosno tamnoga razdoblja, ka razdoblju dužih dana svjetlije razdoblje.

Zaokružujući pogled na pojam kračuna, taj primjer predstavlja potvrdu da je u tradiciji koju nasljeduju i Rusini postojalo promišljanje o odnosima svjetla i tame. Naime, upravo su duge zimske noći mogle ostaviti trag na kulturno i duhovno stanje naroda koji je iz generacije u generaciju svake zime sjedio u tami i čekao tople sunčane dane. Iz te perspektive sunce svojim produženim boravkom na nebeskom svodu čini svojevrsnu "pobjedu" nad tamom i započinje razdoblje dužih, svjetlijih i toplijih dana. Potvrdu toga možemo vidjeti i u rusinskom narodnom običaju koji je zabilježen po kazivanju Olgice Lukač. Gospođa Lukač prisjeća se da je u selu gdje je odrastala (Bikić Dol) na prvi dan Božića u rusinskoj tradiciji kuhana juha isključivo od svinjetine, a nikako od kokošjega mesa. Tumačenje kaže da kokoš nogama kopa unazad, a svinja nosom kopa unaprijed te se kuhanjem juhe od svinjetine nastoji napraviti odmak od asocijativne slike kokošjega kopanja unazad, odnosno gledanja unazad u prošlost i tamne dane koji su prošli. Cilj je držati se asocijativne slike svinjskoga kopanje nosom unaprijed, što čini slikovitu otvorenost budućnosti i boljim i sretnijim danima koji dolaze nakon prijelaza u novo sunčano razdoblje.

Crkva je još u antičko doba nastojala nadići stari kult sunca te se je tako najprije na zapadu, u vrijeme zimskoga solsticija počelo slaviti Kristovo rođenje, koji je u duhu pretkršćanske tradicije nazvan "sunce pravde" — Krist, naš Bog, koji se tada rađa kao "mlado sunce" kako bi nas otkupio od tame grijeha. Rusinska tradicija pokazuje nam da su elementi toga pretkršćanskoga kulta očuvani praktično sve do danas.

\subsection{Božićni post kod Rusina}

Uoči Božića Rusini drže četrdesetodnevni post. To je kršćansko sveto vrijeme priprave za Kristovo rođenje. Završetak posta je 24. prosinca odnosno, 6. siječnja $\mathrm{s}$ večernjim molitvama u crkvi koje se kod Rusina nazivaju sanočne. Izraz sanočne potječe od starije riječi vsenočne, što bi se moglo opisno prevesti "cjelonočno (služenje)". Već sam naziv govori nam da je Crkva u prošlosti prilagodila molitve terminu poganskoga bdijenja na Badnjak kako bi bar dio puka odbila od slavljenja poganske tradicije.

Post je snažan poziv na čišćenje duše i tijela kroz molitvu, činjenje dobrih dijela i uzdržavanje od loših misli i želja, a također i od mesa i masne hrane. Upravo stoga vrijedi istaknuti karakterističnu praksu povezanu s početkom božićnoga posta. Premda je praksa kod Rusina napuštena početkom 20. stoljeća, nje se po priči svojega djeda još uvijek prisjeća kazivač Miron Dudaš. Opisujući događaj s početku posta, on navodi kako je gotovo svako domaćinstvo "obredno" isku- 
havalo posuđe u kojem je tijekom godine kuhano u posebnim glinenim pećima. ${ }^{5}$ Posuđe bi bilo posloženo u kotao i iskuhavano u vrućoj vodi. Kako bi se okorjela masnoća nakupljena tijekom razdoblja uporabe lakše skinula, u vodu je dodavan i pepeo izgorjeloga drveta. ${ }^{6} \mathrm{Na}$ to pranje posuđa narod je potaknut vjerskim tumačenjem da posuđe treba očistiti od nakupljene masnoće kako ona u postu ne bi onečistila nemrsnu hranu predviđenu za post. Iskuhavanje posuđa zabilježeno je i kod Srba dan nakon Božićnih poklada 14.-27. studeni (Bosić, 1996, 22).

Rusini su 1751. godine na prostorima današnje Vojvodine naseljeni uz potporu tadašnje države kako bi sudjelovali u kultiviranju močvarnoga zemljišta, a tu su im uvjeti okruženja diktirali i uvjete življenja. U tom kontekstu primjer "obrednoga" pranja posuđa pokazuje nam na koji način duhovna praksa pomaže uređenju kvalitete praktičnoga života unutar jedne zajednice. Stoga to "obredno" pranje posuđa u vrijeme posta možemo vidjeti kao duhovno svjetlo koje pobjeđuje tamu neznanja. S današnje točke gledanja mi “obrednost” pranja posuđa nalazimo u domeni utjecaja Crkve u vrijeme posta, te možemo naslutiti da je Crkva Božićni post, koji je zajedno s ispovijedi predviđen za duhovno očišćenje, prepoznala kao priliku i za fizičko očišćenje kroz praksu "obrednoga" pranja posuđa. Oslanjajući se na elemente pretkršćanske duhovnosti, gdje se na kraju toga istoga razdoblja vidi Kračun (svjetlo koje pobjeđuje tamu), tako je to sveto vrijeme posta uzdignuto kao duhovno svjetlo koje u tami teških životnih uvjeta narodu pročišćuje i duh i tijelo.

\section{Blagdan sv. Andrije}

\subsection{Elementi pretkršćanskih ishodišta}

Manji blagdan na početku božićnoga posta blagdan je sv. Andrije, koji se slavi 30. studenoga ili 13. prosinca. Sv. Andriju slavi se kao apostola koji je prvi prihvatio Kristov poziv i zbog toga je nazvan pervozvani, odnosno "prvopozvani”.

Narodna tradicija vezana uz blagdan sv. Andrije karakteristično je djevojačka i tu je sv. Andrija prikazan kao zaštitnik ljubavi. Ukrajinski etnolog Mušinka zabilježio je u selu Ruski Krstur običaj nazvan "sijanje konoplje": u noći uoči blagdana djevojka pred prozorom momka zasije nekoliko sjemenki konoplje recitirajući pjesmicu: »Andrija, Andrija, konoplju t sijem na tvoju badnju večer. Daj mi noćas znati s kim ću je žeti? « Majke mladića pred čijom kućom se sve to odigrava već su dobro znaju za tu noćnu aktivnost te, čim djevojke završe sa svojim bajanjem, one izlaze na ulicu vičući: »Aaa, da Bog da da se do iduće godine po udajete! « (Mušinka, 1988, 51).

5 Taj tip peći u narodu je nazivan rusinska peć.

6 Pepeo u svojem sastavu između ostaloga sadržava i kemijske elemente natrija i kalija, čiji se spojevi i u industriji rabe za izradu sredstava za skidanje masnoće, ali i za izradu sapuna. U doba naših predaka deterdžent nije postojao, ali topla voda u kombinaciji s pepelom uspješno je uklanjala okorjelu masnoću. 
Promatrajući djevojačku noćnu aktivnost, možemo vidjeti svojevrsni obred. Prije svega tu je mistična kretnja koju vidimo u sijanju sjemenja konoplje pred mladićevom kućom. Zatim magične riječi koje čujemo u recitaciji kojom se traži odgovor od duhovnoga bića zvanoga Andrej, a koji očito nije kršćanski svetac Andrija, jer je za razgovor s njim dovoljna kršćanska molitva. Nakon toga slijedi odgovor na djevojačko pitanje, koji čujemo kroz krik majčinoga "proklinjanja": »Aaa, da Bog da da se do iduće godine po udajete!« Možemo naslutiti da cilj uzvika najvjerojatnije nije puko tjeranje djevojke ispred mladićeve kuće, nego i izazivanje raznih osjećaja. Naime, vjerovanje kaže da će onaj mladić kojega će djevojka te noći usnuti biti njezin suđeni. Na kraju, tu je i magijski predmet, a to je u ovom slučaju upravo sjeme konoplje, koja simbolizira plodnost.

Drugi dio običaja u vezi s tim blagdanom nazvan je "nošenje Andriška". U njemu grupa mladih djevojaka na dan sv. Andrije oblači jednu djevojku, često malo krupniju, u staru mušku odjeću, na lice joj stavlja masku te ju nazivaju Andriška. ${ }^{7}$ Djevojke su Andrišku nosile na leđima, kao da se rugaju njegovoj muževnosti, pa je događaj dosta komičan. Krećući se u grupi, djevojke vode maskiranu djevojku kroz selo posjećujući one obitelji u kojima živi domaćin s imenom Andrija, ali i ona mjesta gdje se tijekom zime okupljaju mladi.

Ako pak nema djevojke koja bi prihvatila biti maskirana, Andriška se izrađuje kao lutka od slame, također nazvana Andriška. I tom prigodom djevojke posjećuju obitelji u kojima živi domaćin Andrija, s tim da se tada predstavljaju kao trgovkinje sjemenjem od konoplje (Mušinka, 1988, 51). Drugi detalji toga običaja nisu zabilježeni, ali možemo primijetiti da se u običaju opet pojavljuje sjeme.

\subsection{Problem konteksta poganske tradicije povezane s blagdanom sv. Andrije}

Etnolog Mušinka zaključuje da je prethodnik kršćanskoga Andrije najvjerojatnije bio neki poganski bog ljubavi kojemu se ne zna ime (Mušinka, 1988, 53). Krsturski učitelj Olejar ${ }^{8}$ smatra da je ta tradicija vezana uz kult konoplje, koja je od davnina važna sirovina za izradu odjeće, te tvrdi da se je tim obredima željelo prenijeti magijsku snagu te biljke i njezinu plodnost na napredak i korist kućanstva i obitelji (Olejar, 1978, 326). Već smo istaknuli da se na isti datum kod rimokatoličkoga i protestantskoga stanovništva u Vojvodini, u Titelu, južnoj Bačkoj, Bečeju, u naseljima sjeverne Bačke u blizini Mađara (Doroslovo) i Šokac (Sonta) slavi sv. Lucija, gdje po tradiciji te večeri maskirane povorke s imenom Lucija, Lucika, Luca posjećuju domaćinstva (Marjanović, 2011, 162).

Osvrt na tumačenja poganske tradicije koja su ponudili Olejar i Mušinka pokazuje nam da još nema ujednačenoga tumačenja te poganske pozadine blagdana. No, prisutnost sličnih elemenata kod drugih naroda u rusinskom okruženju

7 Etimologija imena Andriška potječe od imena Andrej. To je kršćansko muško ime koje se pojavljuje u Poljskoj, Slovačkoj, Češkoj, Sloveniji, Hrvatskoj, Srbiji i Rusiji, a dolazi od grčkoga imena

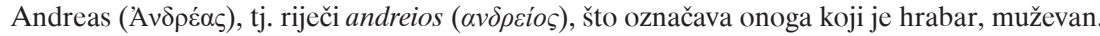

8 Janko Olejar (1928.-1994.), učitelj u Đurđevu i Ruskom Krsturu te direktor Doma kultur u Ruskom Krsturu. Objavljeni su mu mnogi etnografski radovi iz rusinske prošlosti u časopisima Нова думки, Шветлоси, Пионирска заградка, Studia ruthenica i drugi. 
poziva nas na usporedbu poznatih elemenata u strukturi tih poganskih običaja s drugim poganskim običajima kako bi dublje proniknuli u značenje tih običaja.

\subsubsection{Prva usporedba}

Prvu paralelu vidimo s poganskom tradicijom blagdana Ivanjskih krijesova, što se slavi u noći 23. na 24. lipnja ili 6. na 7. srpnja. To je poganski blagdan koji se je slavio u vrijeme suvremenoga blagdana rođenja sv. Ivana Krstitelja. Premda je dio narodnih običaja bio karakteristično proljetni, još u davnini običaji su se pomicali ka blagdanu Ivanjskih krijesova kada su Slaveni slavili najduži dan, odnosno najkraću noć u godini — ljetni solsticij. ${ }^{9}$ Bio je to festival vode, radosti, plodnosti i obilnosti (Szyjewsky, 2003, 146). Zbog mnogih aktivnosti oko vode, koja je asocijativno slična krštenju koje je Ivan Krstitelj provodio na Jordanu, poganski je blagdan u procesu kristijanizacije dobio ime Kupalo, od glagola kupati.

Postojalo je više slavenskih obreda povezanih s ljetnim solsticijem, ali najpoznatiji je onaj kad su mladi nosili lutku od slame na obalu rijeke ili jezera. U zavisnosti od određenoga kraja, lutka je mogla biti ženskoga ili muškoga spola, ali karakteristično je da je bila obučena u odjeću suprotnoga spola. Lutka bi na obali bila spaljena ili bi bila bačena u vodu (Frazer, 2003, 602). U Ukrajini duhovno biće koje vlada vodama u rijekama i jezerima zove se Marena i smatra se da je osobito aktivno u noći Ivana Kupala (Kuibida, 2015, 477).

Možemo primijetiti karakterističnu sličnost te lutke od slame s lutkom koja se kod Rusina pojavljuje na blagdan sv. Andrije, osobito što je lutka obučena u odjeću suprotnoga spola od onoga koji predstavlja, jednako kao što to čine djevojke oblačeći lutka Andrišku.

\subsubsection{Druga usporedba}

Druga paralela usmjerena je na običaj koji se na blagdan Ivanjskih krijesova odvijao noću u šumi. Naime, mladi bi se te noći razišli šumom tražeći cvijet paprati. Po poljskoj, bjeloruskoj, ukrajinskoj i ruskoj tradiciji govorilo se je da onoga koji te noći nađe taj cvijet očekuje velika radost jer time stječe ključ za skriveno blago (Frazer, 2003, 670). Mnogi bi te noći lutali šumama, naprijed su išle djevojke s vijencima na glavi, a za njima su išli dečki. Prisjetimo se samo da je paprat biljka koja nema cvijet te da se razmnožava pomoću spora. Međutim tradicija kaže da »traženje toga cvijeta pomaže cvjetanju odnosa među onima koji sudjeluju u traganju«. Poljski etnolog Andrzej Szyjewsky $(2003,147)$ navodi da je ta noć bila veliki moralni pad muškaraca i dječaka i velika sramota za žene i djevojke.

Magični obred traženja cvijeta paprati po nekim načelima sličan je magičnomu obredu "sijanja konoplje" pred kućom mladića, koji su prakticirale rusinske djevojke noć uoči blagdana sv. Andrije. Osobito stoga što su djevojke upravo te noći očekivale odgovor na mistično pitanje: "Daj mi noćas znati s kim ću je žeti?"

9 Sunce se u ljetnom solsticiju nalazi oko 22. lipnja. 
Očekujući odgovor tko će biti njihov suđeni, one su očekivale svoje najveće "blago". Istu stvar rade i oni koji noć uči Ivanja u šumi traže cvijet paprati i naravno da velika radost čeka onoga tko to uspije, upravo kao da je otkrio blago.

Sagledavanjem tih dviju paralela vidimo da oba blagdana sadržavaju pojmove mladosti, ljubavi, strasti i prokreacije. Iz tih pretpostavki možemo zaključiti da pretkršćanski običaji u pozadini blagdana sv. Andrije slave istu pogansku duhovnost koja se slavi i na pretkršćanski blagdan Ivanjskih krijesova, a to je kult plodnosti.

Premda taj zaključak na novi način rasvjetljava problem spomenute poganske tradicije blagdana sv. Andrije, on istodobno otvara pitanje zašto bi ljetni kult plodnosti povezan s poganskom tradicijom na Ivanjske krijesove bio slavljen na početku zimskoga ciklusa. Jedan od mogućih odgovora nazire se upravo u drugom dijelu mitološke slike povezane s ivanjskim kultom, a to su elementi tame, zime, hladnoće i smrti. Naime, već smo spomenuli da je na Ivanje na obali rijeke ili jezera spaljivana lutka od slame ili je bacana u vodu. Prisutnost elemenata vatre i vode naglašava razliku između toploga i hladnoga, između svjetlosti vatre i tame vodenih dubina. Iz toga možemo primijetiti da na ljetni solsticij postoji dijalektička borba tih dviju suprotnosti. Na početku zimskoga razdoblja u pretkršćanskoj tradiciji kod Rusina postoji slična dijalektika svjetla i tame. Načelo svjetla, topline i života vidimo u elementima kulta plodnosti, čiji se tragovi nalaze u pozadini blagdana sv. Andrije, a odnos prema tami, hladnoći i smrti možemo vidjeti u poganskoj pozadini blagdana sv. Barbare.

\section{Elementi poganske pozadine blagdana sv. Barbare}

Velika mučenica za kršćansku vjeru sv. Barbara slavi se 4. ili 17. prosinca, a slavi ju i istočna i zapadna Crkva. Kod vojvođanskih Bunjevaca na taj se dan nije prelo, šilo ni tkalo, ali je bilo dopušteno peći kruh, a kod Rusna nije bilo dopušteno peći kruh (Olejar, 1978, 327). U Bikić Dolu na Barbaru se kuha pšenica za jelo. Već smo spomenuli da je kod Srba u Vojvodini kuhanje zrna pšenice poznato u više sela, s tim da je u Bođanima, Berkasovu i Šajkašu bio običaj da se prvi tanjur kuhane pšenice nosi na groblje, što znači da je kuhana pšenica, a s tim i blagdan, imala i zadušni karakter (Bosić, 1996, 27). Kod Srba žene od blagdana sv. Andrije do Božića ne snuju pređu za tkanje »da zvijeri ne bi davile stoku « (Bosić, 1996, 25).

U rusinskom selu Kucura ${ }^{10}$ zabilježen je običaj da se na taj dan jedna osoba maskira u Barbaru. Ta "Barbara" oblači se u bijele plahte, brašnom izbijeli lice, od krumpira načini lažne zube, u ruku uzme vreteno i udara njime one koji tog dana predu (Mušinka, 1988, 60), pokazujući time kako se »na blagdan Barbare ne radi na prelu«. U srpskoj tradiciji sv. Petka ili Paraskeva slavi se 14. ili 27. listopada, a smatra se za zaštitnicom žena, rodilja i nemoćnih. Toga se dana ne rade ženski poslovi, ne prede se, ne tka i ne plete. U prošlosti se je na taj dan mijesio 
kolač, a u nekim selima kuhan je kukuruz za jelo, i dio kukuruza odnosio se na groblje. Postoji tumačenje da se kult sv. Petke dovodi u vezu s kultom poganske božice Mokoš (Bosić, 1996, 388). Već smo istaknuli da su Hrvatima u Banatu (u Boki i Neuzini) i Šokcima, Hrvatima i Slovacima u Srijemu, u te dane djevojke, njih dvije do pet, maskirane u bijele haljine ili odjevene u bijele plahte. Glava je obično bila prekrivena rešetom, preko kojega je prebačen bijeli čaršaf, a na prednje je zube pričvršćen jedan veći "zub" od krumpira. U rukama su nosili tavu sa žarom ili metle (Marjanović, 2011, 162).

Sve pobrojane deskripcije običaja pomažu nam zaključiti da kod raznih vojvođanskih naroda postoje velike sličnosti u običajima, što je pak moglo značiti da ti običaji imaju zajedničku tradiciju.

Također je interesantno primijetiti da je pogansko božanstvo Morena kod istočnih Slavena zaštitnica žena i ženskih poslova, osobito prela, a na sjeveru Rusije isto ili slično božanstvo nazivaju Mokuša ili Mokoš, a prikazuje se kao žena s velikom glavom i dugim noktima. To božanstvo bilo je prisutno i kod zapadnih Slavena (Szyjewski, 2003, 128).

Istraživanje Janka Olejara slaže se s tim da se u Krsturu na blagdan sv. Barbare nije smjelo presti, ali dodaje da su mladi kod Rusina na taj blagdan krišom izlazili iz domova tražeći “žrtvu”. Djevojke traže dečke, a dečki djevojke, koji su toga dana prekršili zabranu rada, a kao kaznu za neposluh polijevali bi ih vodom. Ako to ne bi uspjeli, polijevali bi barem kvake na njihovoj kapiji. Prolivena voda do jutra bi se trebala zalediti, a onaj za koga je prolivena na tom bi se ledu trebao okliznuti i pasti (Olejar, 1978, 327). Jasno je da je za stvaranje leda neophodan mraz, a za to je u slavenskoj tradiciji odgovorno božanstvo Morena.

U Moravskoj na blagdan sv. Barbare postoje takozvane Barbórke (Barburke). To su žene koje se tom prilikom oblače u bijelo platno i idu od kuće do kuće darujući dobru djecu, najčešće orasima i jabukama, a zlu i neposlušnu djecu tuku (Mušinka, 1988, 60). Sličnost vidimo u kazivanju gospođe Melanije Dudaš, koja kaže da je u njezinoj mladosti za blagdan sv. Barbare u selu Ruski Krstur postojao običaj: "gdje se jedan muškarac oblačio u žensku bijelu odjeću s bijelom maramom na glavi te bi tako obučen išao na mjesta gdje su se mladi družili te je tom prilikom toliko tukao prisutne dečke da su oni bježeći skoro vrata razvalili”.

Primijetimo da kod svih pobrojanih slučajeva iz pretkršćanske tradicije u vrijeme slavljenja blagdana sv. Barbare vidimo neke osobe obučene u žensko bijelo ruho, predstavljajući na takav način mitsko žensko stvorenje, koje nagrađuje dobre i poslušne, ali još je važnije to što kažnjava zle i one koji ne poštuju neke propise. Bijela boja ruha ukazuje na bijelu boju zime, a agresivnost koja se pojavljuje u tom gotovo ritualnom kažnjavanju neposlušnih potiče emociju straha i osjećaj za opasnost. Možemo zaključiti da običaj toga "obrednoga” kažnjavanja i plašenja dolazi iz davnine te da ima za cilj skretanje pozornosti na glavnu opasnost koja se u tom razdoblju primiče, a to je zapravo zima, koja donosi tamu, hladnoću, glad, bolest i smrt. To potvrđuje njemačka tradicija, koja sv. Barbaru štuje kao zaštitnicu rudara i raznih drugih tamnih podzemnih prostorija, a poslovica njemačkih seljaka kaže: »An Barbara die Sonne weicht / an Lucia sie sich 
wieder zeigt«, tj. da na blagdan sv. Barbare "sunce pravi mjesta Barbari” () jer su dani sve kraći, a noći sve duže — dolazi zima.

Nakon usporedbe poznatih elemenata pretkršćanske tradicije možemo zaključiti da se u razdoblju u kojem mi danas slavimo blagdan sv. Barbare u prošlosti slavila božica zime, tame i smrti, koja je kod Slavena poznatu pod imenom Morena. Etimološki ime Morena znači “ona koja mori, odnosno ubija”. Ona je božica smrti ljudskoga, životinjskoga i biljnoga svijeta, a ubija hladnoćom, odnosno mrazom, stoga je se treba bojati i izbjegavati njezin utjecaj. Simbolizira i "umiranje sunca", odnosno njegovo sve kraće prisustvo na nebu, a početak kraja vladavine toga tamnoga razdoblja kod Rusina obilježava se nazivom kračun za fenomen kada sunce u astronomskom smislu "iskoračuje" iz dugih tamnih hladnih noći, koje sa sobom donose smrt, ka sve dužim, toplijim i svjetlijim danima, koji donose život.

\section{Zaključak}

Osvrtom na narodne običaje u pozadini blagdana sv. Andrije i sv. Barbare, kao uvodnim blagdanima kračunskoga (božićnoga) ciklusa, mogli smo primijetiti da njihov sadržaj obuhvaća elemente kulta plodnosti, odnosno topline, svjetla, radosti i života - pozadina blagdana sv. Andrije, i s druge strane blagdan sv. Barbare, u čijoj pozadini vidimo elemente poganske tradicije povezane s tamom, hladnoćom, strahom, bolešću i smrti. Kako se u liturgijskom kalendaru ta dva blagdana nalaze u neposrednoj blizini, jer ih dijele samo četiri dana, možemo zaključiti da bi poganska tradicija u njihovoj pozadini mogla biti dio istoga kulta u kojem se kroz narodne običaje realiziraju spomenuta suprotna načela (svjetlo i tama), a koji su pak u procesu pokrštavanja dobili svoje kršćanske zaštitnike te su se tako kroz vrijeme podijelili u dva odvojena kršćanska blagdana. Promatramo li ta dva blagdana kao blagdanski par, stječemo mogućnost povlačenja paralele između pretkršćanske tradicije u pozadini toga blagdanskoga para i poganske tradicije blagdana Ivanjskih krijesova, kod kojega se također realiziraju suprotna načela materijalizirana kroz vatru i vodu - dvjema suprotnostima kroz koje se ostvaruje dijalektika svjetla i tame. Tu smo pak simbole svjetla, topline i plodnosti vidjeli u zapaljenoj vatri oko koje mladi plešu i preskaču ju, a simbole tame, hladnoće i smrti, odnosno načela poganske božice Morene, vidimo u riječnoj ili jezerskoj vodi u kojoj se mladi kupaju.

Paralelna usporedba mitoloških slika poganske tradicije koja se zbiva u pozadini blagdanskoga para s poganskom tradicijom Ivanjskih krijesova nudi jedan mogući odgovor zašto se kod Rusina sadržaj poganskoga kulta plodnosti prakticira na početku zimskoga razdoblja, što je još prije pedeset godina zanimalo krsturskoga učitelja Olejara, a kasnije i etnologa Mikolu Mušinku. Naime, na blagdan Ivanjskih krijesova, kroz sliku dijalektičkoga odnosa svjetla, ljubavi i plodnosti s jedne strane te tame, straha, bolesti i smrti s druge, nastoji se istaknuti veličinu nadolazećega ljeta, kojemu se narod raduje zbog njegove svjetlosti, topline i života koji buja. Slično, ali obrnuto, na početku zimskoga ciklusa karakte- 
ristični atributi blagdana Ivanjskih krijesova (toplina, ljubav i plodnost) prisutni u poganskoj pozadini blagdana sv. Andrije, a atributi Morene prisutni su u pozadini blagdana sv. Barbare. Međutim, dijalektički odnos unutar toga blagdanskoga para tom prilikom nastoji istaknuti opasnost koju donosi zima, odnosno ono čega se u tom razdoblju ljudi trebaju bojati, a to je tama, hladnoća, bolest i smrt.

Ta se teorija oslanja na pretpostavku da se prilikom širenja kršćanstva među slavenskim narodima Crkva susretala s brojnim poganskim kultovima i obredima te da je, u nastojanju kristijanizacije, prilikom njihove proslave istodobno slavila određenoga kršćanskoga svetca kao zaštitnika kršćana. Moleći duhovni zagovor pojedinoga svetca, Crkva je molila i za nadilaženje određenoga poganskoga kulta. No, kao što i uzrečica kaže, "bolje da propadne selo nego običaj”, tako je i narod stoljećima nakon primanja kršćanstva i dalje slavio svoje stoljetne običaje.

Vidimo da se je rad na evangelizaciji slavenskih naroda susreo s poganskom tradicijom bogatom elementima animizma, totemizma, pa čak i šamanizma. To nam govori da Rusini u Vojvodini, a s njima i Rusini u Vukovarsko-srijemskoj županiji u Hrvatskoj, nasljeduju širu mitološku tradiciju. To nikako ne treba sagledavati kao nešto negativno, jer nam upravo proučavanje te tradicije otvara mogućnost za bolje upoznavanje zaboravljene povijesti toga naroda. Sagledavajući običaje, dotičemo mitsku pozadinu, po čemu možemo vidjeti odnos naroda sa životnim okruženjem i njegovo nastojanje da riješi probleme koji ga okružuju. Istodobno vidimo na koji je način suživot nastao iz prihvaćanja kršćanstva prosvjetljavao jedan narod, ali i kako je gradio Crkvu te kako su dijelovi narodne tradicije uzdizani s razine pukoga poganskoga praznovjerja i rane čovjekove potrage za Bogom k pravoj Istini kršćanske vjere.

\section{Literatura}

Bešker, Inoslav (2004). Goli blagdani. Zagreb: Naklada Jesenski i Turk.

Bosić, Mila (1996). Годишьи обичаји Срба у Војводини. Нови Сад: Музеј Војводине.

Frazer, James George (2003). Zlatna Grana. Beograd: Ivanišević.

Gavazzi, Milovan (1991). Godinu dana hrvatskih narodnih običaja. Zagreb: Hrvatski sabor kulture.

Kuibida, Victor Vitalievich (2015). Марена. U: Енциклопедичний словник символів культури України. Переяслав-Хмельниц. держ. пед. ун-т імені Григорія Сковороди. ur. В.П. Коцура, О.І. Потапенка, В.В. Куйбіди. (str. 477). Корсунь-Шевченківський. Видавець В.М Гавришенко.

Marjanović, Vesna (2011). Обредне поворке, игрокази и литургијске драме у зимском циклусу обичаја на простору Србије. Зборник ВШССОВ, 6(2), 161-180.

Mušinka, Mikola (1988). Фолклор Руснацох Войводини. Нови Сад: Руске Слово.

Olejar, Janko (1978). Годишњи обичаји у Руском Крстуру. U: Рад ХX удружења фолклориста Југославије у Новом Саду 1973. Београд:

Plotnikova, A. A (2004). Этнолингвистическая география Южний Славини. Москва: Индрик.

Ramač, Julijan (2017). Словнїк Руского народного язика: II: $O-Я$. Нови Сад: Руске Слово.

Szyjewsky Andrzej (2003). Religia Stowian. Kraków: Widawnictwo WAM. 
Elements of the Pagan Tradition in the Pre-Christmas Holidays of the Ruthenians in Vojvodina

\section{Vladimir Edelinski Mikolka*}

\section{Summary}

The article studies elements of the pre-Christian tradition existing in the background of the Christian holidays celebrated by the Ruthenians of Vojvodina.

The aim of this paper is to illustrate the manner in which the pagan tradition influenced the development of the external form which these holidays have taken. An analysis of particular folk customs that exist in the background of the pre-Christmas holiday period, i.e. at the beginning of the winter cycle, specifically on the feast days of St. Andrew and St. Barbara, and a comparison with similar elements existing in pagan customs of the beginning of the summer cycle, enable us to see that elements of the pagan tradition contain a kind of mythological dialectic between light and darkness. At the same time, our research sheds light on certain problems encountered by the Church in the baptizing of pagan nations.

Key words: Ruthenians; holidays; pagan tradition; light and darkness

* Vladimir Edelinski Mikolka, Doctorand, Faculty of Philosophy and Religious Studies, University of Zagreb. Address: Jordanovac 110, 10000 Zagreb, Croatia. E-mail: mikolka.rk@gmail.com 